\title{
In reply to the response of the Letter to the Editor regarding Lipoedema - myths and facts, Part 1 and Part 5. European Best Practice of Lipoedema - Summary of the European Lipoedema Forum consensus
}

We find the publication of the Response Letter [1] an unprofessional and regrettable decision on the part of the authors and editorial staff, given its factual inaccuracies. We have posted our reply to the inaccuracies here: www.lipedema.org/ phlebologie-letter.

\section{Conflict of Interest}

The authors declare that they have no conflict of interest.

Authors

\section{Felicitie Daftuar}

Correspondence

Felicitie Daftuar

Founder \& Executive Director

felicitie@lipedema.org

www.lipedema.org

\section{References}

[1] Tobias B, Gabriele E. Response to the Letter to the Editor regarding Lipoedema - myths and facts, Part 1 and Part 5. European Best Practice of Lipoedema - Summary of the European Lipoedema Forum consensus. Phlebologie 2020; 49: 31-49. doi:10.1055/a-1250-3334
Publication note

\section{Letters to the editor do not necessarily represent the opinion of the editor or publisher. The editor and publisher reserve the right to not publish letters to the editor, or to publish them abbreviated or in extracts.}

Bibliography

Phlebologie 2021; 50: 21

Published online: March 19, 2021

DOI 10.1055/a-1335-7687

ISSN 0939-978X

(c) 2021. Thieme. All rights reserved. Georg Thieme Verlag KG, Rüdigerstraße 14, 70469 Stuttgart, Germany 